\title{
Practical Exploration of Using "Cloud Classroom" to Organize Online Learning: A Case Study of Jianye District, Nanjing during the COVID-19 Pneumonia
}

\author{
Su Dong \\ Teacher Development Center, Jianye District, Nanjing 210019, Jiangsu, \\ China
}

\begin{abstract}
In the case of COVID-19 pneumonia, how to carry out "School's Out, But Class's On", i.e. suspending classes without stopping learning, is not only a problem to be solved by schools, but also a problem that education administrative departments need to solve. During the epidemic, the Education Bureau of Jianye District in Nanjing actively responded to the government's call to implement the "School's Out, But Class's On" policy. I will introduce the specific measures to implement "School's Out, But Class's On" in the Jianye District of Nanjing, Jiangsu Province of China.
\end{abstract}

Sci Insigt Edu Front 2020; 5(2):553-556.

Doi: 10.15354/sief.20.rp016

Keywords: COVID-19; School's Out, But Class's On; Jianye Cloud Classroom; Strategy; Region

Correspondence to: Su Dong, Teacher Development Center, Jianye District, Nanjing 210019, Jiangsu, China. Email: 496609324@qq.com.

Conflict of Interests: None. 
INCE February 4th, 2020, the Leading Group of the Ministry of Education for the COVID-19 Epidemic has issued three guiding documents including "Guiding Opinions on the Implementation of Online Teaching Organization and Management in Colleges and Universities During the Epidemic", "Notice to Support Education and Teaching with Informatization during the Epidemic" and "Notice on Several Issues in Targeted Teacher Work during the Epidemic Prevention and Control". It is proposed that schools use the online platform to guide students to realize "School's Out, But Class's On", aka "suspending classes without stopping learning", during the COVID-19 epidemic (Zhou, et al., 2020).

On February 12th, the Ministry of Education and the Ministry of Industry and Information Technology jointly issued the "Notice on the Work Arrangement of 'School's Out, But Class's On' During the Postponed Spring Semester'. It is required to adhere to the principle of unified provincial-level deployment and implementation of measures tailored to local conditions in various schools, make overall arrangements, open an education cloud platform, and use the Internet to achieve "School's Out, But Class's On" to provide support and guarantee for students' home study (Ministry of Education of the People's Republic of China, 2020).

After the release of the document by the Ministry of Education, the Education Bureau of Jianye District in Nanjing paid special attention, organized and responded actively, and held video conferences. We studied and issued a document as "Notice of Jianye District on the Implementation of the Work of "School's Out, But Class's On" in Response to the Epidemic". It guided the entire district to use "Internet +" technology to carry out online teaching in an orderly manner. We adhered to the "province, city, district, and school" four-level synergic cooperation to provide guidance, service, and guarantee for students' home study.

\section{Make Good Use of Provincial and Municipal Air Classroom Platforms and Resources}

In response to the severe epidemic and the postponed Spring semester, platforms such as "Jiangsu Famous Teachers Air Classroom" and Nanjing "Jinling Micro School" provide comprehensive courses and online Q \& A services for elementary and middle school students. The Teacher Development Center of Jianye District issued a notice to widely publicize the elementary and middle school students in the district, and actively use the platforms and resources. At the same time, we organized outstanding teachers in the district to answer questions for students online; and cooperated with provincial and municipal teaching and research departments to develop high-quality learning resources.

\section{Organize "Jianye Cloud Classroom" Online Learning}

\section{Build "Jianye Cloud Classroom" Online Learning Platform}


In order to provide high-quality online self-learning platforms for elementary and middle school students in the district, the Jianye District Education Technology Office has established a "Jianye Cloud Classroom" network platform (http://ykt.jyedu.cn) to organize online learning for elementary and middle school students. The Teacher Development Center organized subject seminars for subject teachers. According to the learning situation and characteristics of students, implement the overall planning and curriculum design of online teaching. At the same time, teaching and research staff lead key teachers in the region to develop high-quality curriculum resources based on the subject knowledge system and learning topics and upload them to the cloud classroom platform. Students can arrange learning independently as needed. At present, the total number of lessons on the Jianye Cloud Classroom Platform is 1,076, including 607 for elementary students and 469 for middle school students.

\section{Opened the "Jianye Cloud Classroom" Cable TV Live Channel}

In order to protect students' eyesight and reduce the time spent watching computers, starting from March 2nd, 2020, Jianye Cloud Classroom had begun to broadcast on the cable TV with the famous teacher's classroom channel jointly created by Jiangsu Education Department and Jiangsu Cable TV. Jiangsu Cable TV has opened up a dedicated live channel for grades 1-9 for Jianye Cloud Classroom. Students watching Jianye Cloud Classes on TV can not only effectively acquire knowledge, but also relieve eye fatigue properly. This measure is welcomed by students and parents.

\section{Instruct the School to Set Up a "Live Class"}

In addition to organizing students to participate in relevant classroom learning activities of provincial, municipal, and district famous teachers' air classrooms, the district's primary and secondary schools also combine their own characteristics and individual needs of school students, relying on live broadcast platform and open live interactive classrooms such as Tencent classrooms, Dingding campus, Seewo, CCTALK, QQ, etc. Subject teachers arrange learning tasks, online tutoring, and answer questions after class in accordance with the learning situation of the students, so that let students learn at home in diversified forms and richer contents.

\section{Improve Technical Support and Guarantee}

In order to ensure the stable operation of the cloud classroom platform, the educational technology department of Jianye District monitors on duty 24 hours a day. Through the collaboration with the Education Metropolitan Area Network and the Nanjing TV Education Museum, through the joint mobilization of the urban area, the distribution of Telecom and China Mobile access users is realized.

At the same time, stored data such as videos and pictures that require high bandwidth and high disk read and write to the cloud, and utilized the capabilities of the CDN cloud to achieve high concurrent access, greatly reducing the pressure on the local 
data center. Since its launch, the platform has been running smoothly, with zero failures and no stutters, and has provided students with a good experience.

Jianye Cloud Classroom is completely open and shared, no registration is required, and it supports login as a "guest" to watch all the micro courses. In addition to meeting the online learning needs of students in the region, the platform and resources of the region and schools are encouraged and encouraged to open to the outside world. Judging from the operation situation, after the Jianye Cloud Class is online, in addition to serving students in the urban area, it is also free of charge to other provinces and cities across the country. Schools in Guangdong, Hubei, and Changzhou and Shuyang in Jiangsu have also used this platform.

\section{References}

Zhou, L., Wu, S., Zhou, M., Li, F. (2020) 'School's Out, But Class' On', The largest online education in the world today: taking china's practical exploration during the covid-19 epidemic prevention and control as an example. Best Evid Chin Edu, 4(2):501-519.
The Ministry of Education of the People's Republic of China. (2020) Notice on the Work Arrangement of "School's Out, But Class's On" During the Extension Period of Elementary and Secondary Schools, 02-12-2020. 